Alternative Rationales for Superior Real Estate Investment Performance: An Empirical Reinterpretation of Prior Research

\author{
Crocker H. Liu \\ New York University \\ David Hartzell \\ University of North Carolina, Chapel Hill \\ Terry V. Grissom \\ Texas A\&M University \\ Wylie Grieg \\ The RREEF Funds
}

January 6, 1990

Author Note

Crocker H. Liu, Assistant Professor of Finance and Real Estate, New York University, Stern School of Business, Department of Finance, 900 Tisch Hall, New York, NY 10003. 
David Hartzell, Assistant Professor of Real Estate, University of North Carolina, School of Business, Chapel Hill, NC 27514.

Terry V. Grissom, Research Economist, Texas A\&M University, Real Estate Research Center, College Station, TX 78743.

Wylie Grieg, Vice President and Director of Research, The RREEF Funds, San Francisco, CA 94108. 


\begin{abstract}
The purpose of this study is to re-evaluate the existing research on superior real estate investment performance and to suggest alternative explanations for previous findings. A portion of this analysis draws on data from the empirical studies reviewed to the extent possible with appraisal data as well as transaction data based on properties sold by the National Council of Real Estate Investment Fiduciaries (NCREIF) members used for studies which do not report their data. Evidence is presented which links superior real estate investment performance to positive excess skewness in the return distribution. The study also shows that there is a greater likelihood that the return distributions having positive excess skewness are associated with returns computed on the basis of appraised values as opposed to transaction prices. In addition to this, the study finds that inflation and the omission of assets from the market proxy also accounts in part for superior real estate investment performance.
\end{abstract}




\section{Alternative Rationales for Superior Real Estate Investment Performance: An Empirical Reinterpretation of Prior Research}

\section{Introduction}

There has evolved a significant real estate literature which examines the performance of direct equity investment in commercial real estate, while early studies concluded that real estate outperforms other asset classes on a risk adjusted basis, problems with data and return calculations are the primary source of these findings. In particular, recent research generally agrees that measuring holding period returns using appraisals to estimate changes in market values leads to series which are smoothed and hence risk adjusted returns are biased. Several articles have attempted to provide explanations supporting the measured levels of risk or have attempted to estimate real estate returns using techniques other than appraisals to measure market values. In general, however, these studies have analyzed a single factor as opposed to considering other factors which might be relevant to explaining the superior performance of real estate as an asset class.

In this critical review of the relevant literature, earlier studies are repositioned within this perspective so that, after correcting and/or adjusting for the factors contributing to excess returns, the question of abnormal performance can be more thoroughly analyzed. In particular, several articles have attempted to explain the existence of abnormal real estate returns by utilizing the following arguments:

(1) Measures of appraisal-based returns do not consider that real estate markets exhibit limited marketability. Hoag (1980) however constructs a real estate series using an 
assumption of continuous trading. The results presented in the current study show that when continuous trading is simulated, real estate does not exhibit abnormal returns.

(2) Abnormal real estate returns may exist because the market proxy utilized in performance studies omits relevant assets, and therefore the tests are not valid. When a more thorough market portfolio is analyzed however, portfolios similar to those used in Miles and Rice (1978) continue to exhibit abnormal performance.

(3) A premium for non-market risk factors biases measures of standard deviation downward and hence risk-adjusted returns upward. While it is difficult to distinguish and measure non-market factors, tests performed in this study show that non-normality, or extramarket risk, of the return series used by Ibbotson and Fall (1979) and Ibbotson and Siegel (1984) contributes to the existence of abnormal returns.

(4) Indivisibility and lumpiness of real estate investments leads to a reduction in the variability of measured returns. Studies using REIT data have shown that some equity REITs outperform the S\&P500 while other REITs have not. Divisible and liquid, any abnormal returns associated with these shares are found to be due in part to inflation and to the omission of real estate from the market proxy rather than to positive skewness.

(5) After adjusting the single factor model for inflation, some appraisal-based returns still tend to exhibit abnormal performance while the transactions based returns perform equivalently to the market.

An underlying finding of this paper is that, after corrections are made for all of these factors, the remaining skewness generally leads to abnormal performance of real estate over several different measures of market return. This finding is limited somewhat when transactions based returns are utilized. 
The remainder of the paper proceeds as follows. Section 2 describes the data sources used in this critique while the methodology employed is discussed in Section 3. Section 4 undertakes to reinterpret the superior real estate performance reported in other studies with respect to factors which might account for superior returns. Section 5 concludes the study with some conclusions and implications for future research.

\section{Data}

The analysis undertaken draws on data from the studies critiqued whenever possible. Where data are not available, several other data sources are employed. All of these latter data series consist of quarterly holding period returns computed for the period from January 1982 to September 1986 unless noted otherwise. ${ }^{1}$ The sources of real estate returns used where data are unavailable follows:

Equity Real Estate Investment Trusts (EREITs). Fourteen EREITs which have continuous prices and dividends over the 1982Q1-1986Q3 period are used in lieu of EREITs which Smith and Shulman (1976) examine. ${ }^{2}$ Quarterly prices and dividends for each EREIT are extracted from the COMPUSTAT tapes and Standard and Poor's Security Owner's Stock Guide.

Commercial, Non-farm Real Estate. Commercial, non-farm real estate returns are obtained from two sources. The first source consists of quarterly return indices for industrial showroom, industrial warehouse, office, and retail properties compiled by the Frank Russell Company (FRC). The total FRC index is also used in the current study. The FRC indexes are value weighted appraisal-based indexes for unlevered properties. 
The second source of commercial real estate returns is from the dissertation of Rebel Cole (RC) (1988). The study reports appraisal-based and hedonic generated quarterly returns for R\&D industrial, industrial warehouse, office and retail properties. The same methodology employed in constructing the FRC indexes is used in developing the appraisal-based return series. On the other hand, transaction-based returns are generated using a hedonic model which is similar in spirit to Hoag (1980). Determinants of real estate value which are incorporated in the hedonic models for various property types are national location, metropolitan location, lease structure, physical structure, and financial performance. Both sets of returns are calculated from a subset of the properties included in the FRC index. The properties in the Cole study are divided into two samples - the sold property sample and a control sample consisting of FRC properties that figured in FRC Index calculations as of December 1986. The actual number of properties in the sold and unsold samples respectively which were used to compute the return indices are 277 and 192 properties.

Two market proxies are also used in the current study to investigate investment performance. The first market proxy is the S\&P500. Quarterly data on this index are from issues of Standard and Poor's Analyst Handbook, Monthly Supplement. The second market proxy is a value weighted US market index (USMI) constructed from six asset categories. The six asset groups are stocks, bonds, cash equivalents, commercial real estate, farmland, and single family homes. The average weights used for each asset class in computing the USMI are depicted in Fig. 1. The market values and underlying data sources used to construct the portfolio weights are discussed in Appendix A. Four versions of the USMI are constructed with a different commercial real estate component employed in each version. The four alternative commercial real estate return series used in constructing the USMI include total FRC returns (USMI1), 
imputed ACLI returns (USMI2), appraisal based returns from the Cole (1988) study (USMI3), and hedonic generated returns from the Cole (1988) study (USMI4). ${ }^{3}$

The sum of the asset submarkets does not represent the 'true' US market portfolio since assets such as human capital and consumer durables are omitted. ${ }^{4}$ A possibility also exists that some assets are overstated. ${ }^{5}$ In addition to this, some smoothing might exist in the USMI index from the return series for farm real estate since this series is based on lenders' estimates of farm prices rather than actual sales. Although the extent of this bias is unknown, Fig. 1 suggests that only a slight bias might exist since farmland represents approximately $8 \%$ of the USMI proxy and ranges from $4.8 \%$ to $11.6 \%$ in any given period. ${ }^{6}$ Despite these shortcomings, the asset classes included do comprise the most liquid and identifiable components of investable capital wealth. The study consequently assumes that the asset categories chosen are a reasonable representation of the investment market-place. Table 1 provides summary statistics for the first three moments of the return distribution associated with the market proxies. A distinctive feature of this exhibit is that the returns on each of the market proxies except for the USMI2 are more or less normally distributed although some negative skewness is associated with the USMI proxies. As expected, a fairly high correlation exists between the various market proxies although the correlation is lower between the S\&P500 and the various versions of the USMI relative to the correlation between the various versions of the USMI.

\section{Methodology}

The performance measure of Jensen (1968) is used to test for abnormal investment performance. ${ }^{7}$ This measure is based on the capital asset pricing model (CAPM) and has the following form 


$$
\tilde{R}_{j t}-r_{f t}=\alpha_{j}+\beta_{j}\left(\tilde{R}_{M t}-r_{f t}\right)+\varepsilon_{j t}
$$

where $\alpha_{j}$ represents the performance index. A positive (negative) alpha implies that portfolio $\mathrm{j}$ exhibits a return which exceeds (is lower than) its expected risk premium. In addition to this, the Brueggeman, Chen and Thibodeau (BCT) (1984) modification of the performance measure of Jensen is used. This modified performance measure uses the excess return on the market portfolio and the excess inflation rate as the first and second factors respectively. The formal model is

$$
\tilde{R}_{j t}-r_{f t}=\alpha_{j}+\beta_{j 1}\left[\tilde{R}_{M t}-r_{f t}\right]+\beta_{j 2}\left[\pi_{t}-r_{f t}\right]+\varepsilon_{t}
$$

where $\left(\tilde{R}_{j t}-r_{f t}\right)$ is the excess return on the $j$ th fund in period $t,\left(\tilde{R}_{M t}-r_{f t}\right)$ is the excess return on the market portfolio in period $t,\left[\pi_{t}-r_{f t}\right]$ is the excess inflation rate in period $t$, and $\alpha_{j}$ is the modified Jensen index.

The Shapiro-Wilk (1965) W-statistic is also used to investigate whether Jensen's alpha is linked to the non-normality of the return distribution. The maximum value of $W$ is 1 with values near 1 indicative of normality. Percentage points associated with the critical $\mathrm{W}$ region are reported in this study as Prob $<W$. Shapiro and Wilk use a Prob $<W$ of $50 \%$ or greater to evidence normality. Excess skewness $\left(\mu^{3}\right)$ is also calculated in addition to the W-statistic to analyse the relationship of Jensen's alpha to skewness.

\section{Fundamental factors which might induce abnormal returns}

\subsection{Limited marketability}

Hoag (1980) has shown that real estate exhibits a similar risk and return to common stocks when a continuous market is simulated for real estate. This implies that a premium exists for limited marketability, from the smoothing of returns inherent in the appraisal process, or 
both. However, several alternative explanations are also consistent with why no superior performance exists for real estate. First, the modified hedonic framework which Hoag uses results in a normally distributed return for real estate. Normality is one of the reasons why the results of Hoag differ from Brueggeman, Chen and Thibodeau (1984), Ibbotson and Siegel (1984), and other real estate studies. Although Hoag does not report his real estate returns, an approximation of these returns is possible. ${ }^{8}$ Figure 2 reports the approximated returns together with the Shapiro-Wilk test for normality. This exhibit reveals that the return distribution which Hoag uses is not statistically different from the normal distribution although some negative skewness is present. To further show that the return distribution rather than limited marketability or an understatement of the variance induces excess returns, Jensen alphas are computed for both commercial real estate returns based on appraisals and on transaction prices for a period subsequent to the Hoag study. The resulting Jensen alphas are shown in Table 2.

The salient feature of this table is that no positive abnormal returns arise when a continuous real estate market exists and returns are measured using actual sale prices regardless of which version of the USMI is used. One reason for this is that the return distribution associated with each hedonic index is negatively skewed. Negative skewness obtains in part because the 1982-86 period over which returns are measured is characterized by disinflation. In contrast to this, positive excess returns are present and significant at the $10 \%$ level for R\&D industrial, industrial warehouse, and retail properties when returns are based on appraisals from either the Cole study or the FRC property portfolio. This result is invariant to which version of the USMI is employed. This suggests that even though Cole et al. (1986) find that on average no statistical difference exists between appraised values and the sale prices, differences do exist when alternative return series are constructed. In particular, the distribution associated with 
appraisal-based returns exhibits positive skewness while negative skewness corresponds to the hedonic generated return distribution. This differential in the distributions leads in turn to different implications of real estate investment performance. However, the statistical significance of these positive excess returns $(\alpha)$ is related in part to the degree of positive excess skewness associated with these returns and the probability that the return distribution is normally distributed. Note that when positive skewness exists but the return distribution approaches normality (Prob $<W \rightarrow 50 \%$ ) as in the case of RC Office (Appraised), FRC Office, and FRC Warehouse, the Jensen alpha is not significant at the 5\% level. Figure 3 shows that there is a tendency for excess returns to increase given an increase in positive excess skewness.

A different level of aggregation used for the real estate returns of Hoag relative to stock returns also biases the results in favor of similar risk adjusted returns for real estate and stock. The investment performance of a specific type of real estate (industrial properties) is compared with a well-diversified stock portfolio (S\&P500). A more appropriate comparison is to compare a diversified real estate portfolio against the S\&P500. When a diversified real estate fund based on hedonic indices is compared with the S\&P500, the results might support the existing empirical evidence. Table 3 shows that when industrial, retail, and office returns generated from hedonic indices are compared with the S\&P500 index, the return per unit of total risk (1/CVj is similar between the S\&P500 and R\&D industrial real estate. This result is consistent with Hoag (1980). Stocks also exhibit a higher return per unit of total risk relative to either retail or office properties as well as when the four property types are combined.

However, one can observe that the total risk associated with the real estate portfolio differs from the risk associated with each property type. This situation obtains since Table 4 shows that not all the returns for the four property types are highly correlated with each other. 
However, different perspectives on the magnitude of the correlation coefficients obtain depending on which set of commercial real estate returns are used in computing these correlation coefficients. When FRC returns are used to compute correlation coefficients, it appears that the four property types are moderately correlated and as such the reduction in portfolio risk from diversifying among property types is nominal at best. On the other hand, a greater reduction in portfolio risk appears to exist when either commercial real estate return series from the Cole (1988) study is used. Table 4 shows that high correlations occur between office and retail and also between the two industrial categories with respect to the hedonic indices. In contrast to this, a high correlation obtains only between retail and R\&D industrial when appraisal based returns from the Cole study are used.

\subsection{Omitted real estate markets}

Both Mayers (1972) and Roll (1977) demonstrate that all assets should fall on the security market line when the market proxy is correctly specified and mean-variance efficient. Correct specification of the market portfolio implies that asset markets other than stocks and bonds such as real estate are explicitly recognized. However, Stambaugh (1982) empirically demonstrates that omitted asset markets inclusive of real estate do not pose a problem in estimating common stock returns. Unfortunately, Stambaugh does not investigate whether the omitted real estate asset market is important with respect to real estate returns.

Miles and Rice (1978) also fail to address whether the addition of real estate to a market proxy eliminates any excess return on real estate although higher betas are shown for farm returns when a more complete market index is used relative to the S\&P500. Not only does the study fail to investigate whether the 11 types of farm real estate examined outperform the S\&P500 but the study also does not examine whether superior performance persists even after 
accounting for systematic real estate market risk. This is because Miles and Rice assume that the CAPM holds and therefore they restrict Jensen's alpha to equal zero in computing betas for farmland. The point is that if real estate continues to exhibit abnormal returns given a more complete market proxy, then the omitted asset phenomenon might not necessarily account for any superior performance. To address the two issues raised, the return data in Miles and Rice (1978, pp. 17) is used. In addition to this, returns on the US market wealth (USMW) portfolio and the world market wealth (WMW) portfolio inclusive of metals is obtained from Ibbotson and Siegel (1983, pp. 13). The USMW and WMW portfolios are used since the Miles and Rice Index (MRI) excludes bonds, metals, international securities, residential real estate, and commercial real estate. The Jensen alphas computed for farm real estate relative to the four market proxies are shown in Table 5. A series of paired $\mathrm{T}$ tests is also undertaken to compare whether the magnitude of Jensen alphas are similar on average across market proxies. Table 6 depicts the results of the paired $\mathrm{T}$ tests.

The noticeable feature of Table 5 is that all 11 types of farm real estate possess positive excess returns across the four market proxies. Another observation is that positive excess skewness $\left(\mu^{3}\right)$ is associated with each farm return with the probability that a return comes from a normal distribution $($ Prob $<W$ ) less than $1 \%$ in general. A weak tendency also exists that Jensen alpha is larger the higher the amount of positive skewness. Positive skewness might arise for farmland since these returns are based on estimates of farmers, lenders, and real estate brokers rather than market transactions. These estimates could also account for the weak relationship of positive skewness to the level of Jensen alpha.

Table 6 shows that the magnitude of Jensen alphas is similar on average for the S\&P500 and the WMW. Jensen alphas on the S\&P500 are also not different from alphas on the USMW at 
the 5\% level of significance. This suggests that Jensen alphas computed with the S\&P500 for farmland are robust over the period investigated. No difference in mean alphas also exists between the USMW and the WMW either at the 5\% or $10 \%$ level of significance. Surprisingly, differences in the level of Jensen alpha exist between the MRI and all other market proxies. One possible explanation for this is that only the MRI includes human capital. Human capital comprises over $62 \%$ of the MRI and has a 0.953 correlation with the MRI. The main point of Tables 5 and 6 is that a more complete market proxy does not necessarily account for superior investment performance if the return distribution is non-normal.

\subsection{Non-market risk}

Ibbotson and Siegel (1984) find evidence that abnormal real estate returns occur even after various types of real estate are included in the market portfolio. This evidence consists of positive Jensen alphas for real estate. Ibbotson and Siegel therefore suggest that non-market risks are priced. The hypothesized market imperfections priced include high transaction and information costs, taxes, and limited marketability. No attempt is made however to ascertain which non-market risk factor has a premium associated with it. An alternative explanation for the finding of Ibbotson and Siegel is that extra-market risk rather than non-market attributes is priced. The extra-market risk that might be priced is positive skewness. This link of skewness to Jensen alpha is readily verifiable using the data in Ibbotson and Fall (1979) and Ibbotson and Siegel $(1983,1984)$. Table 7 depicts the results of this verification process.

The distinguishing feature of Table 7 is that alpha decreases given a decrease in the degree to which property returns exhibit positive excess skewness. Notice that as the probability of normality (Prob $<\mathrm{W}$ ) increases from single family homes and farmland to commercial real estate, the level of alpha falls. Commercial real estate not only has the lowest alpha of the three 
property types but also the $\mathrm{T}$ value associated with the Jensen alpha decreases. This finding is invariant to whether excess returns are adjusted or unadjusted for inflation. In fact, Table 7 reveals that the unadjusted Jensen alphas are almost identical to the Jensen alphas adjusted for inflation using the Brueggeman, Chen and Thibodeau (1984) CAPMUI model. Therefore, while non-market forces may contribute to abnormal real estate performance results, non-normality also appears to be a significant contributing factor. The link of positive skewness to Jensen alpha in Table 7, however, is only suggestive in nature and does not convey the extent to which skewness is important in determining the required rate of return. Moreover, the present study uses a measure of total skewness rather than looking at systematic skewness or co-skewness. Arditti (1975) argues that the only way to ascertain if skewness is incorporated in the market pricing of assets is through the use of an equilibrium model. Without an equilibrium model, the relationship shown in Table 7 might not necessarily exist. ${ }^{9}$

\subsection{Indivisibility or asset lumpiness}

Another reason suggested for the existence of abnormal returns is asset lumpiness or indivisibility. However, Draper and Findlay (1982) argue that any superior performance which arises from this imperfection is short term in nature since no entry restrictions exist for financial intermediaries to perform arbitrage. Consequently, neither asset lumpiness nor indivisibility should cause abnormal returns to occur over a long enough time period. The finding of Smith and Shulman (1976) that equity REITs exhibit similar investment performance to closed end investment companies on average is consistent with this implication. However, the reported results show that some EREITs exhibit superior performance. A question not answered is whether fundamental factors exist which might account for any abnormal EREIT returns. 
Abnormal returns might occur for equity REITs given an omission of real estate from the market proxy since Smith and Shulman use the S\&P Composite.

To gain an additional insight into the investment performance of EREITs, Jensen alphas are calculated for 15 EREITs over the 1982 to 1986 period with the S\&P500 used as the market proxy. Table 8 shows the relationship of skewness and non-normality to Jensen alphas for EREITs. Observe that superior investment performance for equity REITs in contrast to direct investment in commercial real estate (see Table 2 and Fig. 3) does not appear to be related to skewness and non-normality of the return distribution. This suggests that other factors account for the superior performance of EREITs. The most likely factors are the omitted asset phenomenon (i.e. the omission of certain assets such as real estate from the market proxy) and inflation since EREITs possess both stock and real estate attributes and real estate is considered a hedge against inflation. ${ }^{10}$ Table 9 lends partial support to the omitted asset hypothesis when ACLI commercial real estate returns are used in the USMI. Only two of the five EREITs which have a positive Jensen alpha with respect to the S\&P500 outperform the USMI with the ACLI real estate component. In contrast, all five EREITs continue to exhibit superior performance when all other commercial real estate return alternatives are used in constructing the USMI. Several plausible explanations could account for this phenomenon. For instance, less EREITs have positive excess returns with respect to using the USMI with the ACLI return component since the imputation process has a higher error variance relative to either real estate returns based on appraised values or actual sale prices. Alternatively, the quality of real estate associated with equity REITs is usually lower relative to the grade of real estate which exists in a CREF or FRC. As such, if the ACLI cap rates include 'mezzanine' type properties then it is possible that the imputed ACLI series would have a stronger correlation with the return on equity REITs relative 
to other commercial real estate return series. Correlations calculated between reach of the four alternative commercial real estate return series and the return on the National Association of REITs Index (NAREIT) are consistent with this rationale. The correlation coefficients between the return on the NAREIT index and the returns on the appraisal based and hedonic generated indices in the Cole (1988) study are -0.10 and -0.22 respectively. On the other hand, the correlation coefficients between the return on the NAREIT index and the returns on the FRC and the ACLI indices are 0.12 and 0.22 respectively.

In contrast to the mixed findings with respect to the omitted asset hypothesis, the magnitude and statistical significance of the excess returns are affected by whether inflation is included as a factor in computing Jensen's alpha. Table 9 reveals that the excess returns associated with both the REIT of California and the Washington REIT are not statistically significant from zero at the $5 \%$ level after the Jensen alpha is modified to account for inflation. This result holds regardless of which market proxy is used. However, Western Investment, Federal Realty, and IRT continue to exhibit superior returns even after inflation is accounted for.

\subsection{Inflation risk}

Brueggeman, Chen and Thibodeau (1984) find that commercial real estate exhibits abnormal returns even after inflation risk is taken into account. Positive two-factor Jensen alphas for two commingled real estate funds evidence this superior performance. A key issue which the study raises is not whether inflation is priced but rather if abnormal real estate returns will continue to persist even after inflation is recognized. Real estate studies such as Fama and Schwert (1977), Miles and McCue (1984), Fogler, Granito and Smith (1985), and Hartzell, Hekman and Miles (1987) have dealt with the former issue but only Brueggeman, Chen and Thibodeau attempt to address the latter concern. 
The data which Brueggeman, et al. use suggest that skewness is associated with the CREF returns. To show that this conjecture is a possibility, Jensen alphas modified for inflation are computed using the same methodology as that employed in the Brueggeman, et al. study and are shown in Table 10. The gross return data for three well diversified insurance CREFs from the first quarter of 1979 to the third quarter of 1986 is used in lieu of the CREFs used in the BCT study. In addition to this, the four major FRC property types are also used. The most distinctive feature of this table is that all three CREFs as well as the FRC property types outperform not only the S\&P500 and GNP but also the USMI with the FRC real estate component even after inflation is accounted for. The only exception to this is the FRC retail category which has the lowest amount of excess skewness associated with it. Moreover, the level of superior investment performance for the three CREFs as well as the four FRC categories appear to be linked in a positive manner to skewness. In general, the modified Jensen alpha decreases as skewness decreases with the investment performance of CREF3 being the only exception to this phenomenon.

\section{Summary and Conclusions}

Roll (1977) demonstrates that no superior investment performance in a CAPM context should arise if the market portfolio consists of all asset categories and is mean-variance efficient. This argument implicitly assumes that either individual returns are normally distributed or that investors possess quadratic utility. The present study suggests that superior investment performance arises in part from a violation of the assumption that returns are normally distributed. The issue which the current study raises is whether the return distribution associated with actual sales prices is normal. If positive skewness still arises when returns are computed 
with actual sales prices then a performance measure based on the Kraus-Litzenberger (1976) CAPM which incorporates skewness preference might provide more meaningful results. Also, third order stochastic dominance might provide a useful property selection criteria to investors if positive skewness exists. An additional implication if the third moment of the return distribution is important is that some modification to the mean-variance allocation of wealth to stocks, bonds, bills, and real estate is necessary. Another finding of the study is that the addition of real estate to a market proxy does not necessarily affect investment performance results. 


\section{Notes}

1. The availability of commercial, non-farm real estate data dictates the time period evaluated. This time interval is primarily characterized by a low level of inflation and as such, the positive real estate return bias prevalent in most real estate investment performance studies is absent in the present study.

2. A large portion of the EREITs which Smith and Shulman investigate have merged, no longer have REIT status, or no longer exist. The remaining EREITs are used in the current study. The EREITs investigated in the current study include California REIT, Federal Realty, First Union, Hollywood Park, Hotel Investors, HRE Properties, IndianaFlorida REIT, IRT, Property Trust of America, REIT of California, Santa Anita Realty, USP REIT, Washington REIT, and Western Investment.

3. The imputed ACLI returns are computed from dividing the capitalization rate into net operating income (NOI) from a large CREF. Among the property types included in this aggregate NOI are industrial, office, and retail properties. Quarterly capitalization rates for these property types are obtained from the American Council of Life Insurance (ACLI) publication Mortgage Commitments on Multifamily and Nonresidential Properties. The 'prices' which result from dividing net operating income by the capitalization rate do not represent specific market transactions but rather are an alternative method of deriving appraised values. The ACLI 'appraised' values differ from the CREF or FRC appraised values in that the latter are based on a mixture of in-house and outside appraisals. In-house appraisals are not necessarily marked to market as is the case with outside appraisals since the value adjustment process might simply reflect increases in capital improvements from the date of the last outside appraisal. On the other 
hand, the ACLI values represent an imperfect attempt to 'mark the value of the properties to market' in each quarter. A referee has pointed out that a higher error variance might exist when ACLI values are used relative to CREF appraised values since the values are estimated without inspecting the subject properties and without the benefit of location specific capitalization rates.

4. The omission of human capital is not trivial since the beta for real estate might be understated and therefore Jensen's alpha might be overstated if real estate is positively correlated with human capital (and is significant) but is uncorrelated with securities. However, the bias which arises from this omitted asset might not be a major concern given the finding of Miles and Rice (1978, pp. 13, Table 2) that the correlation of real estate with human capital is 0.016 .

5. Double counting might arise since multiple financial claims on the same underlying asset are present. Corporations holding common stock of another corporation is one example of this dilemma. Another example is real estate and real estate mortgages. The current study attempts to avoid the latter type of double counting through using only the total equity value for various property types.

6. If the market proxy is smoothed and the real estate return series is not smoothed then the real estate alpha is understated while the associated standard error of the alpha estimate is overstated. This in turn biases the results towards a false acceptance of the CAPM on real estate.

7. One can argue that performance tests should utilize either a multi-factor model or the arbitrage pricing model given the problems associated with the single factor performance measure of Jensen. A major problem with the Jensen measure is that the model assumes 
that any measured abnormal performance can only exist if the market proxy is inefficient. However, Dybvig and Ross (1985) show that the Jensen measure will correctly detect abnormal performance if managers do not possess any market timing ability but do have the ability to select securities. Moreover, Lehmann and Modest (1987, pp.263) state that 'there are considerable differences between the performance measures yielded by the standard CAPM benchmarks and those produced with APT benchmarks, which suggests the importance of knowing the appropriate model for risk and expected return in this context'. Not knowing the appropriate model, we believe that the CAPM represents an appropriate starting point for our critical literature review, and we regard performance tests based on the APT or multi-factor model as extensions of this paper.

8. One can approximate returns from a Xerox enlargement of Figure II in Hoag (1980, pp. 578).

9. We evaluate the impact of skewness on returns in the context of the Kraus and Litzenberger (1976) version of the CAPM in a companion paper by Liu, Hartzell and Grissom (1990). The Kraus-Litzenberger model assumes that investors prefer positive skewness in their portfolios and that all investors hold the market portfolio. Given these assumptions, the model predicts that investors will underprice assets with positive systematic skewness if the market is negatively skewed. Conversely, investors will bid up the price of assets with positive systematic skewness in the presence of a positively skewed market. The theory also holds if the market portfolio is symmetric in the return distribution and individual assets exhibit co-skewness with the market.

10. For example, Mengden and Hartzell (1986) find preliminary evidence that equity REITs are hybrid securities. 
11. The summary statistics are computed using excess returns on the assets and market proxies i.e. nominal asset returns minus the risk free rate. The USMI1, USMI2, USMI3 and USMI4 are the four versions of the USMI proxy with the FRC, ACLI, R. Cole (1988) appraisal, and R. Cole (1988) hedonic return series used respectively as the commercial real estate component in the USMI index. The measure of skewness reported $\left(\mu^{3}\right)$ is the total skewness rather than systematic skewness or co-skewness.

12. $1 / \mathrm{CV}$ is the reciprocal of the coefficient of variation. The coefficient of variation is defined as $\sigma / \bar{x}$. 


\section{Appendix A}

The market values used to construct the portfolio weights in Fig. 1 and returns are obtained as follows:

1. Cash equivalents. Values and returns for 90 to 119 day commercial paper and 90 day bankers' acceptances are taken from the Federal Reserve Bulletin. Values for 3-month Treasury bills are also obtained from the Federal Reserve Bulletin with returns computed from issues of Economic Indicators.

2. Corporate bonds, US government bonds, and mortgage backed bonds. Aggregate market values and returns for corporate, government, and mortgage backed bonds are obtained from the Shearson-Lehman publication The Bond Market Annual Report.

3. Common stock. Market values and returns associated with the Media General Composite Index (MGCI) are taken from various issues of Media General Financial Weekly. The index consists of common shares for all corporations traded on the NYSE, ASE, and NASDAQ. Ibbotson and Fall (1979) have used the market value of the MGCI as a proxy for the aggregate value of all stocks in the construction of a US market wealth portfolio.

4. Commercial real estate. Aggregate value estimates for nonresidential commercial real estate are taken from Musgrave (1981) and subsequent issues of the Survey of Current Business. The series for current dollar net stock of non-corporate nonresidential structures is chosen to avoid double counting corporate real estate. Farm structures are factored out from this total. The aggregate land value is obtained from the Board of Governors of the Federal Reserve System publication Balance Sheets for the US Economy 1945-86. The mortgage amount outstanding for non-residential income 
producing properties taken from the Federal Reserve's Annual Statistical Series is subtracted from the total market value to yield the equity value.

5. Farm real estate. The market value of farms are taken from Farm Real Estate Market Developments and Agricultural Land Values and Markets. Real estate debt reported in Economic Indicators of the Farm Sector: National Financial Summary 1985 is subtracted from this total value to generate total farm equity.

Farm returns are based on the average quarterly price per acre for 11 types of farmland from the Federal Reserve Bank of Kansas City. Income is obtained from the US Department of Agriculture publications Farm Real Estate Market Developments and Agricultural Land Values and Markets.

6. Single family homes. The aggregate value of single family residential structures is taken from the US Department of Commerce publication Fixed Reproducible Tangible Wealth in the United States 1925-85. The series used is the current dollar net stock of non-farm 1-4 unit structures. Aggregate residential land values are taken from Balance Sheets for the US Economy 1945-86. The aggregate home mortgage debt quoted in the Federal Reserve publication Annual Statistical Series is next subtracted from this total value to arrive at single family home equity.

Monthly weighted average sale prices on new and existing homes for 27 metropolitan statistical areas are obtained from the Federal Home Loan Bank Board. The data includes only houses financed with conventional first mortgage loans. Monthly median rents, vacancies, and operating expenses are obtained from the US Bureau of the Census publication Annual Housing Survey: Summary of Housing Characteristics for Selected Metropolitan Areas, H-171 Series. 
Table 1a. Summary statistics on the market proxies. ${ }^{11}$

\begin{tabular}{llllll}
\hline Asset & $a$ & $G$ & $\mu 3$ & $W$ & Prob $<W$ \\
\hline SP500 & 0.026 & 0.070 & 0.180 & 0.962 & 0.60 \\
USMI1 & 0.000 & 0.028 & 0.034 & 0.950 & 0.44 \\
USMI2 & 0.017 & 0.031 & -0.055 & 0.928 & 0.22 \\
USMI3 & 0.007 & 0.027 & -0.020 & 0.951 & 0.45 \\
USMI4 & 0.007 & 0.028 & -0.029 & 0.964 & 0.65 \\
\hline
\end{tabular}

Table 1b. Summary statistics on the market proxies ${ }^{.11}$

\begin{tabular}{|c|c|c|c|c|c|}
\hline \multirow[b]{2}{*}{ Asset } & \multicolumn{5}{|c|}{ Correlation coefficients } \\
\hline & SP500 & USMI1 & USMI2 & USMI3 & USMI4 \\
\hline SP500 & 1.00 & & & & \\
\hline USMI1 & 0.71 & 1.00 & & & \\
\hline USMI2 & 0.69 & 0.93 & 1.00 & & \\
\hline USMI3 & 0.70 & 0.99 & 0.93 & 1.00 & \\
\hline USMI4 & 0.64 & 0.94 & 0.81 & 0.95 & 1.00 \\
\hline
\end{tabular}

\section{Legend:}

USMI1 = USMI with FRC returns used for the commercial real estate component.

USMI2 = USMI with imputed ACL1 returns used for the commercial real estate component. USMI3 = USMI with appraisal returns from Cole (1988) used for the commercial real estate component.

USMI4 = USMI with hedonic returns from Cole (1988) used for the commercial real estate component. 
Table 2. Jensen alphas computed using USMI market proxy, 1982Q1-1986Q3.

\begin{tabular}{|c|c|c|c|c|c|c|}
\hline Asset & $O L$ & $\mathrm{~T}(\mathrm{a})$ & Prob $>\mid \mathrm{T}$ & | Skewness & $W$ & Prob $<W$ \\
\hline \multicolumn{7}{|c|}{ USMI with FRC real estate component } \\
\hline $\begin{array}{l}\text { RC R\&D Industrial } \\
\text { (Appraised) }\end{array}$ & 0.010 & 2.82 & 0.01 & 1.50 & 0.834 & $<0.01$ \\
\hline RC Retail (Appraised) & 0.006 & 1.78 & 0.09 & 1.40 & 0.884 & 0.03 \\
\hline RC Warehouse (Appraised) & 0.006 & 2.45 & 0.03 & 0.63 & 0.934 & 0.28 \\
\hline RC Office (Appraised) & 0.006 & 1.70 & 0.11 & 0.46 & 0.946 & 0.40 \\
\hline RC Office (Hedonic) & 0.013 & 0.58 & 0.57 & -0.66 & 0.939 & 0.32 \\
\hline RC Retail (Hedonic) & 0.008 & 0.70 & 0.49 & -0.71 & 0.913 & 0.09 \\
\hline RC Warehouse (Hedonic) & -0.003 & -1.12 & 0.28 & -1.00 & 0.845 & $<0.01$ \\
\hline $\begin{array}{l}\text { RC R\&D Industrial } \\
\text { (Hedonic) }\end{array}$ & -0.009 & -1.84 & 0.08 & -1.00 & 0.903 & 0.06 \\
\hline FRC R\&D Industrial & 0.012 & 2.41 & 0.03 & 3.70 & 0.501 & $<0.01$ \\
\hline FRC Office & 0.002 & 1.02 & 0.32 & 0.68 & 0.952 & 0.45 \\
\hline FRC Retail & 0.007 & 2.12 & 0.05 & 0.39 & 0.910 & 0.08 \\
\hline FRC Warehouse & 0.004 & 1.94 & 0.07 & -0.03 & 0.969 & 0.74 \\
\hline \multicolumn{7}{|c|}{ USMI with R. Cole appraisal real estate component } \\
\hline $\begin{array}{l}\text { RC R\&D Industrial } \\
\text { (Appraised) }\end{array}$ & 0.010 & 2.81 & 0.01 & 1.50 & 0.834 & $<0.01$ \\
\hline RC Retail (Appraised) & 0.006 & 1.76 & 0.09 & 1.40 & 0.884 & 0.03 \\
\hline RC Warehouse (Appraised) & 0.006 & 2.44 & 0.03 & 0.63 & 0.934 & 0.28 \\
\hline RC Office (Appraised) & 0.006 & 1.68 & 0.11 & 0.46 & 0.946 & 0.40 \\
\hline RC Office (Hedonic) & 0.013 & 0.57 & 0.57 & -0.66 & 0.939 & 0.32 \\
\hline RC Retail (Hedonic) & 0.008 & 0.68 & 0.51 & -0.71 & 0.913 & 0.09 \\
\hline RC Warehouse (Hedonic) & -0.003 & -1.14 & 0.27 & -1.00 & 0.845 & $<0.01$ \\
\hline $\begin{array}{l}\text { RC R\&D Industrial } \\
\text { (Hedonic) }\end{array}$ & -0.009 & -1.89 & 0.08 & -1.00 & 0.903 & 0.06 \\
\hline FRC R\&D Industrial & 0.012 & 2.41 & 0.03 & 3.70 & 0.501 & $<0.01$ \\
\hline FRC Office & 0.002 & 1.03 & 0.32 & 0.68 & 0.952 & 0.45 \\
\hline FRC Retail & 0.007 & 2.10 & 0.05 & 0.39 & 0.910 & 0.08 \\
\hline FRC Warehouse & 0.004 & 1.92 & 0.07 & -0.03 & 0.969 & 0.74 \\
\hline \multicolumn{7}{|c|}{ USMI with R. Cole hedonic real estate component } \\
\hline RC R\&D Industrial & 0.010 & 2.94 & 0.01 & 1.50 & 0.834 & $<0.01$ \\
\hline
\end{tabular}




\begin{tabular}{|c|c|c|c|c|c|c|}
\hline \multicolumn{7}{|l|}{ (Appraised) } \\
\hline RC Retail (Appraised) & 0.006 & 1.74 & 0.09 & 1.40 & 0.884 & 0.03 \\
\hline RC Warehouse (Appraised) & 0.006 & 2.43 & 0.03 & 0.63 & 0.934 & 0.28 \\
\hline RC Office (Appraised) & 0.006 & 1.75 & 0.11 & 0.46 & 0.946 & 0.40 \\
\hline RC Office (Hedonic) & 0.006 & 0.25 & 0.80 & -0.66 & 0.939 & 0.32 \\
\hline RC Retail (Hedonic) & 0.005 & 0.43 & 0.68 & -0.71 & 0.913 & 0.09 \\
\hline RC Warehouse (Hedonic) & -0.003 & -1.19 & 0.25 & -1.00 & 0.845 & $<0.01$ \\
\hline $\begin{array}{l}\text { RC R\&D Industrial } \\
\text { (Hedonic) }\end{array}$ & -0.009 & -1.99 & 0.06 & -1.00 & 0.903 & 0.06 \\
\hline FRC R\&D Industrial & 0.012 & 2.46 & 0.02 & 3.70 & 0.501 & $<0.01$ \\
\hline FRC Office & 0.003 & 1.16 & 0.26 & 0.68 & 0.952 & 0.45 \\
\hline FRC Retail & 0.007 & 2.14 & 0.05 & 0.39 & 0.910 & 0.08 \\
\hline FRC Warehouse & 0.004 & 1.93 & 0.07 & -0.03 & 0.969 & 0.74 \\
\hline \multicolumn{7}{|c|}{ USMI with imputed ACLI real estate component } \\
\hline $\begin{array}{l}\text { RC R\&D Industrial } \\
\text { (Appraised) }\end{array}$ & 0.010 & 2.39 & 0.03 & 1.50 & 0.834 & $<0.01$ \\
\hline RC Retail (Appraised) & 0.006 & 1.74 & 0.09 & 1.40 & 0.884 & 0.03 \\
\hline RC Warehouse (Appraised) & 0.006 & 2.38 & 0.03 & 0.63 & 0.934 & 0.28 \\
\hline RC Office (Appraised) & 0.006 & 1.75 & 0.11 & 0.46 & 0.946 & 0.40 \\
\hline RC Office (Hedonic) & 0.029 & 1.19 & 0.25 & -0.66 & 0.939 & 0.32 \\
\hline RC Retail (Hedonic) & 0.014 & 1.12 & 0.29 & -0.71 & 0.913 & 0.09 \\
\hline RC Warehouse (Hedonic) & -0.003 & -0.95 & 0.35 & -1.00 & 0.845 & $<0.01$ \\
\hline $\begin{array}{l}\text { RC R\&D Industrial } \\
\text { (Hedonic) }\end{array}$ & -0.008 & -1.53 & 0.15 & -1.00 & 0.903 & 0.06 \\
\hline FRC R\&D Industrial & 0.014 & 2.72 & 0.01 & 3.70 & 0.501 & $<0.01$ \\
\hline FRC Office & 0.003 & 1.09 & 0.29 & 0.68 & 0.952 & 0.45 \\
\hline FRC Retail & 0.007 & 2.12 & 0.05 & 0.39 & 0.910 & 0.08 \\
\hline FRC Warehouse & 0.004 & 1.72 & 0.10 & -0.03 & 0.969 & 0.74 \\
\hline
\end{tabular}


Table 3. Comparison of real estate to stocks 1982Q1-1986Q3 ${ }^{12}$

\begin{tabular}{|c|c|c|c|c|c|c|}
\hline & Retail & Office & Warehouse & $\mathbf{R} \& \mathbf{D}$ & VW RE & S\&P 500 \\
\hline \multicolumn{7}{|c|}{ FRC commercial real estate data } \\
\hline Mean & 0.028 & 0.024 & 0.026 & 0.032 & 0.025 & 0.047 \\
\hline Standard Deviation & 0.012 & 0.010 & 0.007 & 0.021 & 0.009 & 0.068 \\
\hline $1 / \mathrm{CV}$ & 2.44 & 2.37 & 3.84 & 1.54 & 2.67 & 0.701 \\
\hline \multicolumn{7}{|c|}{$\begin{array}{l}\text { R. Cole commercial real } \\
\text { estate data using } \\
\text { appraisals }\end{array}$} \\
\hline Mean & 0.027 & 0.026 & 0.027 & 0.032 & 0.027 & 0.047 \\
\hline Standard Deviation & 0.013 & 0.015 & 0.009 & 0.015 & 0.011 & 0.068 \\
\hline $1 / \mathrm{CV}$ & 2.05 & 1.75 & 3.00 & 2.06 & 2.49 & 0.701 \\
\hline \multicolumn{7}{|c|}{$\begin{array}{l}\text { R. Cole commercial real } \\
\text { estate data using hedonic } \\
\text { indices }\end{array}$} \\
\hline Mean & 0.029 & 0.031 & 0.019 & 0.014 & 0.027 & 0.047 \\
\hline Standard Deviation & 0.046 & 0.095 & 0.008 & 0.018 & 0.052 & 0.068 \\
\hline $1 / \mathrm{CV}$ & 0.626 & 0.332 & 2.51 & 0.768 & 0.517 & 0.701 \\
\hline
\end{tabular}


Table 4. Correlation of commercial real estate returns 1982Q2-1986Q3.

\begin{tabular}{|c|c|c|c|c|}
\hline & Retail & Office & Warehouse & $\mathrm{R} \& \mathrm{D}$ Industrial \\
\hline \multicolumn{5}{|c|}{ FRC commercial real estate returns } \\
\hline Retail & 1.00 & & & \\
\hline Office & 0.65 & 1.00 & & \\
\hline Warehouse & 0.75 & 0.53 & 1.00 & \\
\hline R\&D Industrial & 0.63 & 0.66 & 0.41 & 1.00 \\
\hline \multicolumn{5}{|c|}{ R. Cole real estate returns using appraisal data } \\
\hline Retail & 1.00 & & & \\
\hline Office & 0.30 & 1.00 & & \\
\hline Warehouse & 0.24 & 0.20 & 1.00 & \\
\hline R\&D Industrial & 0.60 & 0.26 & 0.36 & 1.00 \\
\hline \multicolumn{5}{|c|}{ R. Cole real estate returns using hedonic indexes } \\
\hline Retail & 1.00 & & & \\
\hline Office & 0.85 & 1.00 & & \\
\hline Warehouse & 0.19 & 0.20 & 1.00 & \\
\hline R\&D Industrial & 0.29 & 0.29 & 0.81 & 1.00 \\
\hline
\end{tabular}


Table 5. Jensen alphas on farm real estate, 1965-75.

\begin{tabular}{|c|c|c|c|c|c|c|c|}
\hline \multirow[b]{2}{*}{ Farm real estate } & \multicolumn{2}{|c|}{ S\&P500 } & \multicolumn{2}{|l|}{ MRI } & \multicolumn{3}{|c|}{ Normality statistics } \\
\hline & $\alpha$ & $\mathrm{T}(\alpha)$ & $\alpha$ & $\mathrm{T}(\alpha)$ & $\mu^{3}$ & $W$ & Prob $<W$ \\
\hline Indiana & 0.094 & 6.35 & 0.095 & 3.26 & 1.21 & 0.852 & $<0.01$ \\
\hline Ohio & 0.069 & 5.73 & 0.060 & 2.83 & 1.91 & 0.817 & $<0.01$ \\
\hline Illinois & 0.095 & 5.62 & 0.082 & 2.49 & 2.07 & 0.803 & $<0.01$ \\
\hline Iowa & 0.104 & 5.78 & 0.091 & 2.52 & 1.85 & 0.802 & $<0.01$ \\
\hline Missouri & 0.102 & 7.09 & 0.074 & 3.43 & 2.79 & 0.710 & $<0.01$ \\
\hline Michigan & 0.065 & 5.85 & 0.039 & 2.41 & 1.43 & 0.834 & $<0.01$ \\
\hline Wisconsin & 0.110 & 10.65 & 0.099 & 5.84 & 1.07 & 0.913 & 0.09 \\
\hline Minnesota & 0.126 & 7.22 & 0.145 & 4.54 & 2.04 & 0.724 & $<0.01$ \\
\hline North Dakota & 0.139 & 6.46 & 0.143 & 3.59 & 2.29 & 0.648 & $<0.01$ \\
\hline South Dakota & 0.116 & 6.43 & 0.112 & 3.52 & 2.34 & 0.697 & $<0.01$ \\
\hline \multirow[t]{2}{*}{ Kansas } & 0.094 & 5.57 & 0.077 & 2.70 & 1.80 & 0.840 & $<0.01$ \\
\hline & \multicolumn{2}{|c|}{ USMW } & \multicolumn{2}{|l|}{ WMW } & \multicolumn{3}{|c|}{ Normality statistics } \\
\hline Farm real estate & $\alpha$ & $\mathrm{T}(\alpha)$ & $\alpha$ & $\mathrm{T}(\alpha)$ & $\mu^{3}$ & $W$ & Prob $<W$ \\
\hline Indiana & 0.097 & 4.46 & 0.096 & 4.20 & 1.21 & 0.852 & $<0.01$ \\
\hline Ohio & 0.070 & 4.37 & 0.068 & 3.98 & 1.91 & 0.817 & $<0.01$ \\
\hline Illinois & 0.098 & 3.98 & 0.096 & 3.65 & 2.07 & 0.803 & $<0.01$ \\
\hline Iowa & 0.115 & 4.61 & 0.112 & 4.03 & 1.85 & 0.802 & $<0.01$ \\
\hline Missouri & 0.102 & 5.41 & 0.110 & 5.20 & 2.79 & 0.710 & $<0.01$ \\
\hline Michigan & 0.058 & 4.23 & 0.054 & 4.01 & 1.43 & 0.834 & $<0.01$ \\
\hline Wisconsin & 0.110 & 8.24 & 0.107 & 7.55 & 1.07 & 0.913 & 0.09 \\
\hline Minnesota & 0.129 & 5.58 & 0.127 & 5.06 & 2.04 & 0.724 & $<0.01$ \\
\hline North Dakota & 0.145 & 4.93 & 0.143 & 4.61 & 2.29 & 0.648 & $<0.01$ \\
\hline South Dakota & 0.120 & 5.27 & 0.118 & 4.83 & 2.34 & 0.697 & $<0.01$ \\
\hline Kansas & 0.097 & 4.33 & 0.094 & 4.02 & 1.80 & 0.840 & $<0.01$ \\
\hline
\end{tabular}


Table 6. Paired T test to compare Jensen alphas on four market proxies.

\begin{tabular}{llcl}
\hline Paired proxies & Mean difference & $\mathrm{T}$ & Prob>|T| \\
\hline S\&P500 and MRI & 0.009 & 2.16 & 0.06 \\
S\&P500 and USMW & -0.002 & 1.85 & 0.09 \\
S\&P500 and WMW & -0.001 & 0.63 & 0.54 \\
MRI and USMW & -0.011 & 3.02 & 0.01 \\
MRI and WMW & -0.010 & 2.38 & 0.04 \\
USMW and WMW & 0.001 & 1.49 & 0.17 \\
\hline
\end{tabular}


Table 7. Jensen alphas and normality statistics

\begin{tabular}{lcclll}
\hline Type of real estate & $\mathrm{a}$ & $\mathrm{T}(\mathrm{a})$ & Skewness & $W$ & Prob $<W$ \\
\hline \multicolumn{2}{l}{ Jensen alpha unadjusted for inflation } & & & & \\
\hline Farmland & 0.080 & 5.26 & 1.29 & 0.906 & 0.01 \\
Single family homes & 0.030 & 7.18 & 1.04 & 0.906 & 0.01 \\
Commercial real estate & 0.016 & 2.58 & 0.38 & 0.956 & 0.46 \\
\hline Jensen alpha adjusted for inflation using BCT model & & & \\
\hline Farmland & 0.080 & 5.26 & 1.29 & 0.906 & 0.01 \\
Single family homes & 0.030 & 7.18 & 1.04 & 0.906 & 0.01 \\
Commercial real estate & 0.017 & 2.58 & 0.38 & 0.956 & 0.46 \\
\hline
\end{tabular}

Legend: $\alpha$ is Jensen's alpha; Skewness is excess skewness; Wis the Shapiro-Wilk (1965) statistic for normality; BCT Model refers to the Brueggeman, Chen and Thibodeau (1984) model.

Source: Jensen alphas computed using the World Market Wealth Portfolio (real estate returns and the market proxy are from Ibbotson data sources). 
Table 8. Relationship of skewness and normality to abnormal returns, 1982Q1-1986Q3.

\begin{tabular}{|c|c|c|c|c|c|c|}
\hline EREIT & $\alpha$ & $\mathrm{T}(\alpha)$ & Prob $>|\mathrm{T}|$ & Skewness & $W$ & Prob $<W$ \\
\hline \multicolumn{7}{|c|}{ EREITs with positive Jensen alpha using S\&P500 } \\
\hline Western Investment & 0.052 & 3.37 & 0.00 & -0.17 & 0.961 & 0.59 \\
\hline Federal Realty & 0.047 & 3.23 & 0.00 & 0.54 & 0.900 & 0.05 \\
\hline IRT & 0.034 & 2.08 & 0.05 & 0.37 & 0.958 & 0.53 \\
\hline REIT of California & 0.032 & 1.94 & 0.07 & 0.40 & 0.962 & 0.61 \\
\hline Washington REIT & 0.029 & 1.75 & 0.10 & 0.21 & 0.901 & 0.05 \\
\hline \multicolumn{7}{|c|}{ EREITs with insignificant Jensen alpha using S\&P500 } \\
\hline First Union & 0.040 & 1.48 & 0.16 & 0.06 & 0.976 & 0.87 \\
\hline United Dominion & 0.038 & 1.67 & 0.11 & 0.90 & 0.926 & 0.20 \\
\hline HRE & 0.027 & 1.47 & 0.16 & 0.70 & 0.940 & 0.33 \\
\hline California REIT & 0.023 & 0.82 & 0.42 & 0.10 & 0.959 & 0.55 \\
\hline Hollywood Park & 0.021 & 0.62 & 0.55 & 0.81 & 0.885 & 0.03 \\
\hline Santa Anita & 0.021 & 0.67 & 0.51 & 0.67 & 0.967 & 0.70 \\
\hline Hotel Investors & 0.010 & 0.63 & 0.54 & -0.42 & 0.965 & 0.66 \\
\hline Indiana-Florida REIT & 0.001 & 0.08 & 0.94 & -0.68 & 0.935 & 0.28 \\
\hline USP Real Estate & -0.008 & -0.28 & 0.79 & 0.51 & 0.975 & 0.84 \\
\hline Property Trust & -0.016 & -0.54 & 0.60 & 1.00 & 0.820 & $<0.01$ \\
\hline
\end{tabular}


Table 9. Equity REITs with positive Jensen alpha when market proxy is S\&P500, 1982Q11986Q3.

\begin{tabular}{|c|c|c|c|c|c|c|}
\hline \multirow[b]{2}{*}{ EREIT } & \multicolumn{3}{|c|}{ Unadjusted for inflation } & \multicolumn{3}{|c|}{ Adjusted for inflation with BCT model } \\
\hline & $\alpha$ & $\mathrm{T}(\alpha)$ & Prob $>|\mathrm{T}|$ & $\alpha$ & $\mathrm{T}(\alpha)$ & Prob $>|\mathrm{T}|$ \\
\hline \multicolumn{7}{|l|}{ S\&P500 } \\
\hline Western Investment & 0.052 & 3.37 & 0.00 & 0.046 & 2.62 & 0.02 \\
\hline Federal Realty & 0.047 & 3.23 & 0.00 & 0.038 & 2.39 & 0.03 \\
\hline IRT & 0.034 & 2.08 & 0.05 & 0.040 & 2.18 & 0.04 \\
\hline REIT of California & 0.032 & 1.94 & 0.07 & 0.028 & 1.47 & 0.16 \\
\hline Washington REIT & 0.029 & 1.75 & 0.10 & 0.016 & 0.93 & 0.37 \\
\hline \multicolumn{7}{|c|}{ USMI with FRC RE component } \\
\hline Western Investment & 0.055 & 3.69 & 0.00 & 0.067 & 2.85 & 0.01 \\
\hline Federal Realty & 0.046 & 4.15 & 0.00 & 0.042 & 3.30 & 0.00 \\
\hline IRT & 0.039 & 2.68 & 0.02 & 0.050 & 3.16 & 0.01 \\
\hline REIT of California & 0.036 & 2.24 & 0.04 & 0.033 & 1.79 & 0.09 \\
\hline Washington REIT & 0.040 & 2.25 & 0.04 & 0.032 & 1.59 & 0.13 \\
\hline \multicolumn{7}{|c|}{ USMI with R. Cole appraisal based data } \\
\hline Western Investment & 0.056 & 3.71 & 0.00 & 0.048 & 2.87 & 0.01 \\
\hline Federal Realty & 0.046 & 4.09 & 0.00 & 0.041 & 3.26 & 0.00 \\
\hline IRT & 0.038 & 2.60 & 0.02 & 0.049 & 3.06 & 0.01 \\
\hline REIT of California & 0.036 & 2.21 & 0.04 & 0.033 & 1.77 & 0.10 \\
\hline Washington REIT & 0.039 & 2.19 & 0.04 & 0.031 & 1.54 & 0.14 \\
\hline \multicolumn{7}{|c|}{ USMI with R. Cole hedonic index } \\
\hline Western Investment & 0.057 & 3.87 & 0.00 & 0.050 & 2.97 & 0.01 \\
\hline Federal Realty & 0.045 & 4.60 & 0.00 & 0.038 & 3.53 & 0.00 \\
\hline IRT & 0.039 & 2.60 & 0.02 & 0.047 & 2.71 & 0.02 \\
\hline REIT of California & 0.036 & 2.24 & 0.04 & 0.032 & 1.70 & 0.11 \\
\hline Washington REIT & 0.042 & 2.15 & 0.05 & 0.029 & 1.34 & 0.20 \\
\hline \multicolumn{7}{|c|}{ USMI with imputed ACLI RE component } \\
\hline Western Investment & 0.054 & 3.25 & 0.00 & 0.049 & 2.73 & 0.01 \\
\hline Federal Realty & 0.038 & 2.64 & 0.02 & 0.034 & 2.22 & 0.04 \\
\hline IRT & 0.028 & 1.52 & 0.15 & 0.037 & 1.94 & 0.07 \\
\hline REIT of California & 0.027 & 1.52 & 0.15 & 0.026 & 1.33 & 0.20 \\
\hline Washington REIT & 0.020 & 1.02 & 0.32 & 0.015 & 0.73 & 0.47 \\
\hline
\end{tabular}


Table 10. Jensen alphas adjusted for inflation with BCT model, 1979Q1-1986Q3.

\begin{tabular}{lccllll}
\hline Asset & $\alpha$ & $\mathrm{T}(\alpha)$ & Prob>|T| & Skewness & $W$ & Prob $<W$ \\
\hline S\&P500 & & & & & & \\
\hline CREF1 & 0.013 & 4.32 & 0.00 & 1.19 & 0.910 & 0.02 \\
CREF2 & 0.006 & 3.45 & 0.00 & 1.09 & 0.902 & 0.01 \\
CREF3 & 0.006 & 2.00 & 0.05 & 2.51 & 0.789 & $<0.01$ \\
FRC RD Industrial & 0.012 & 3.34 & 0.00 & 3.33 & 0.659 & $<0.01$ \\
FRC Office & 0.010 & 2.80 & 0.01 & 1.53 & 0.876 & $<0.01$ \\
FRC Warehouse & 0.007 & 3.32 & 0.00 & 0.90 & 0.955 & 0.32 \\
FRC Retail & 0.002 & 0.96 & 0.35 & 0.41 & 0.945 & 0.17 \\
\hline USMI with FRC real estate component & & & & & \\
\hline CREF1 & 0.010 & 4.07 & 0.00 & 1.19 & 0.910 & 0.02 \\
CREF2 & 0.007 & 3.57 & 0.00 & 1.09 & 0.902 & 0.01 \\
CREF3 & 0.006 & 2.09 & 0.05 & 2.51 & 0.789 & $<0.01$ \\
FRC RD Industrial & 0.012 & 3.47 & 0.00 & 3.33 & 0.659 & $<0.01$ \\
FRC Office & 0.010 & 2.74 & 0.01 & 1.53 & 0.876 & $<0.01$ \\
FRC Warehouse & 0.007 & 3.45 & 0.00 & 0.90 & 0.955 & 0.32 \\
FRC Retail & 0.003 & 1.67 & 0.25 & 0.41 & 0.945 & 0.17 \\
\hline Gross National Product (GNP) & & & & & & \\
\hline CREF1 & 0.017 & 2.92 & 0.01 & 1.19 & 0.910 & 0.02 \\
CREF2 & 0.016 & 5.67 & 0.00 & 1.09 & 0.902 & 0.01 \\
CREF 3 & 0.010 & 2.01 & 0.05 & 2.51 & 0.789 & $<0.01$ \\
FRC RD Industrial & 0.012 & 3.47 & 0.00 & 3.33 & 0.659 & $<0.01$ \\
FRC Office & 0.010 & 2.74 & 0.01 & 1.53 & 0.876 & $<0.01$ \\
FRC Warehouse & 0.007 & 3.45 & 0.00 & 0.90 & 0.955 & 0.32 \\
FRC Retail & 0.003 & 1.17 & 0.25 & 0.41 & 0.945 & 0.17 \\
\hline & & & & & &
\end{tabular}




\begin{tabular}{lllllll}
\hline & Stocks & Bonds & Cash & Commercial RE & Farms & Homes \\
\hline Minimum weight & 0.182 & 0.105 & 0.077 & 0.155 & 0.048 & 0.237 \\
Maximum weight & 0.291 & 0.199 & 0.086 & 0.197 & 0.116 & 0.317 \\
Average weight & 0.239 & 0.150 & 0.082 & 0.175 & 0.081 & 0.274 \\
Standard deviation & 0.029 & 0.027 & 0.003 & 0.012 & 0.022 & 0.023 \\
\hline
\end{tabular}

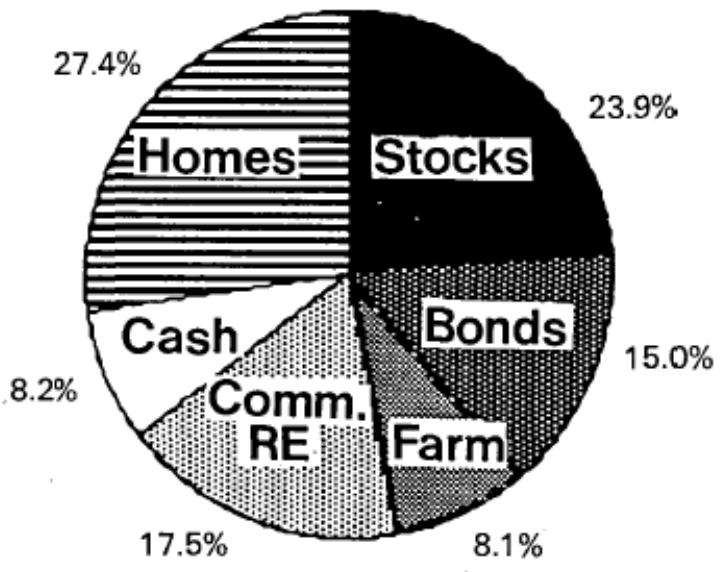

Figure 1. Market weights for US market proxy, 1982Q1-1986Q3. 


\begin{tabular}{cclrc}
\hline Year & Quarter 1 & Quarter 2 & Quarter 3 & Quarter 4 \\
\hline 1973 & 0.025 & 0.050 & -0.120 & 0.190 \\
1974 & -0.005 & 0.000 & 0.040 & 0.075 \\
1975 & -0.160 & 0.135 & 0.057 & -0.060 \\
1976 & -0.070 & 0.265 & -0.280 & 0.060 \\
1977 & 0.025 & 0.100 & 0.057 & 0.170 \\
1978 & -0.080 & 0.090 & 0.265 & \\
\hline
\end{tabular}

Mean: 0.036 Standard Deviation: 0.129

Skewness: -0.350 Shapiro-Wilk W: $0.971 \quad$ Prob $<W: 0.69$

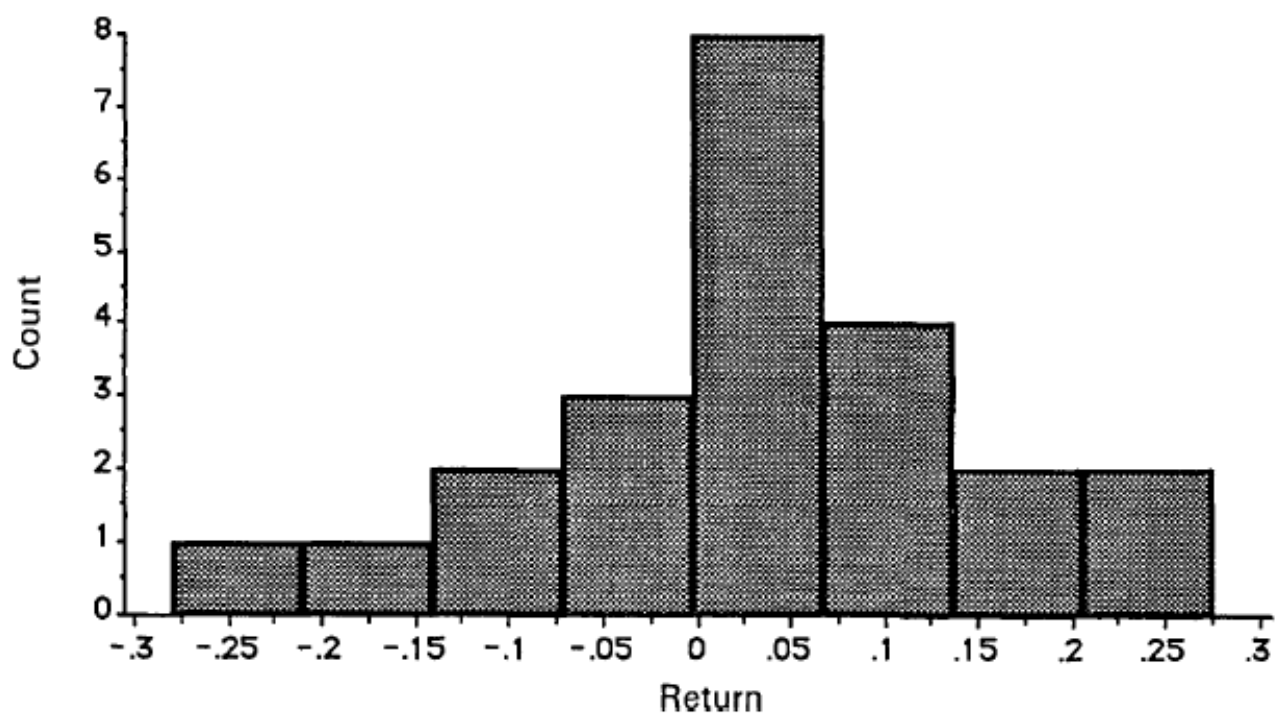

Figure 2. Approximation of industrial real estate returns in Hoag (1980). 


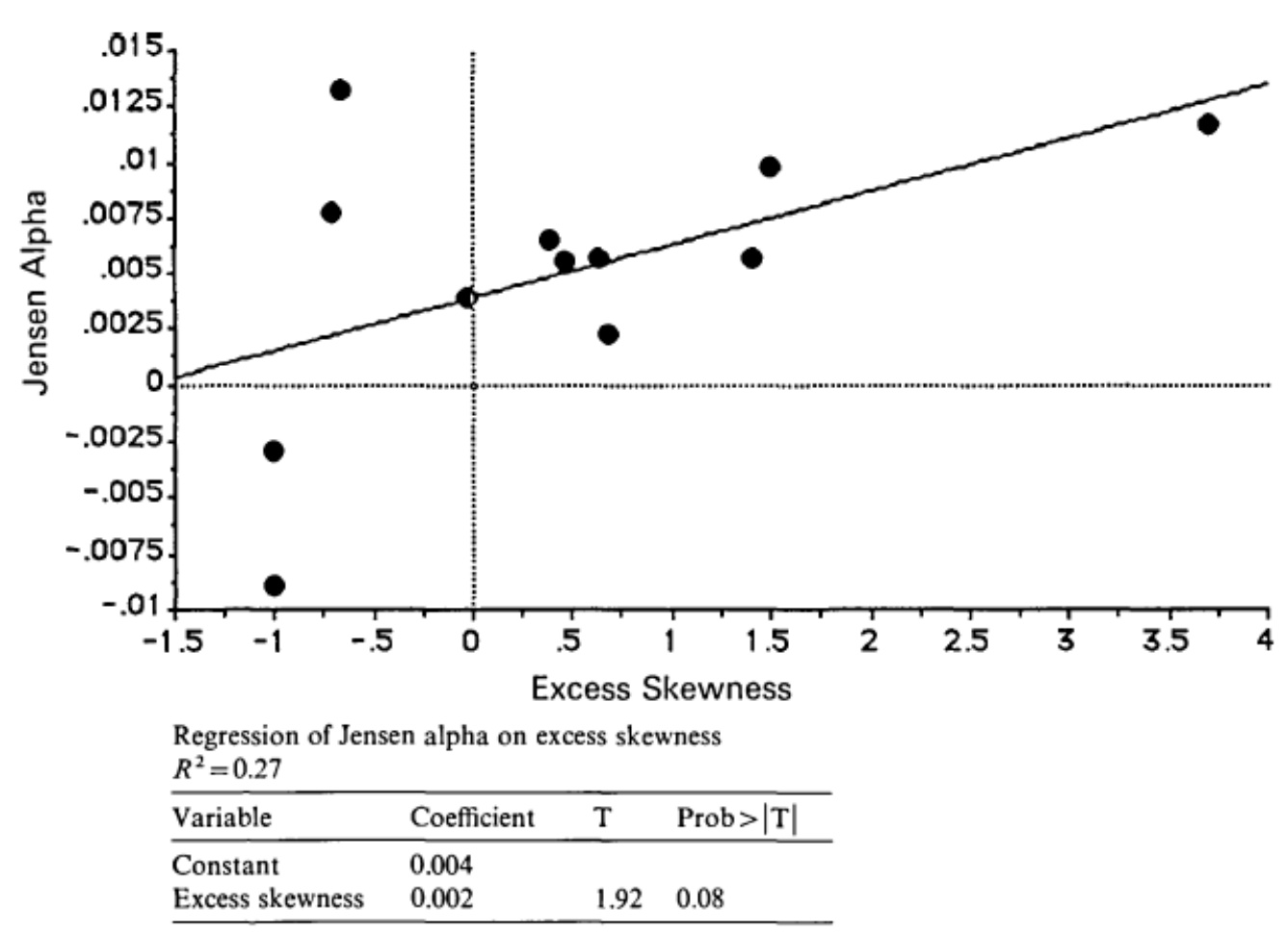

Figure 3. Graph of Table 2 (USMI with FRC component): Jensen alpha versus excess skewness. 


\section{References}

Arditti, F.D. (1975) Skewness and investors' decision: a reply, Journal of Financial and Quantitative Analysis, 10(1), 173-6.

Brueggeman, W., Chen, A. and Thibodeau, T. (1984) Real estate investment funds: performance and portfolio considerations, AREUEA Journal, 12(3), 333-54.

Cole, R., Guilkey, D. and Miles, M. (1986) Toward an assessment of the reliability of commercial appraisals, Appraisal Journal, 54(3), 422-32.

Draper, D.W. and Chapman Findlay III, M. (1982) Capital asset pricing and real estate valuation, AREUEA Journal, 10(2), 152-83.

Dybvig, P.H. and Ross, S.A. (1985) Differential information and performance measurement using a security market line, Journal of Finance, 40(2), 383-99.

Dybvig, P.H. and Ross, S.A. (1985) The analytics of performance measurement using a security market line, Journal of Finance, 40(2), 401-16.

Fama, E.F. and Schwert, G.W. (1977) Asset returns and inflation, Journal of Financial Economics, 5(2), 115-46.

Fogler, H.R., Granito, M.R.and Smith, L.R. (1985) A theoretical analysis of real estate returns, Journal of Finance, 40(3), 711-19.

Friedman, H.C. (1971) Real estate investment and portfolio theory, Journal of Financial and Quantitative Analysis 6(2), 861-74.

Hartzell, D., Hekman, J. and Miles, M. (1987) Real estate returns and inflation, AREUEA Journal, 15(1), 617-37.

Hoag, J.W. (1980) Towards indices of real estate value and return, Journal of Finance, 35(2), 569-80. 
Ibbotson, R.G. and Fall, C.L. (1979) The United States market wealth portfolio, Journal of Portfolio Management, 6(1), 82-92.

Ibbotson, R.G. and Siegel, L.B. (1983) The world market wealth portfolio, Journal of Portfolio Management, 9(2), 5-17.

Ibbotson, R.G. and Siegel, L.B. (1984) Real estate returns: a comparison with other investments, AREUEA Journal, 12(3), 219-42.

Jaffe, AJ. and Sirmans, C.F. (1984) The theory and evidence on real estate financial decisions: a review of the issues, AREUEA Journal, 12(3), 378-400.

Kraus, A. and Litzenberger, R.H. (1976) Skewness preference and the valuation of risky assets, Journal of Finance, 31(4), 1085-100.

Lehmann, B.N. and Modest, D.M. (1987) Mutual fund performance evaluation: a comparison of benchmarks and benchmark comparisons, Journal of Finance, 42(2), 233-65.

Liu, C.H. (1988) Market Imperfections, Omitted Asset Markets, and Abnormal Real Estate Returns: A Theoretical and Empirical Investigation, $\mathrm{PhD}$ dissertation, University of Texas, Austin, Texas.

Liu, C.H., Hartzell, D.J., Grissom, T.V. and Greig, W. (1989) Skewness as a Rationale for Superior Real Estate Investment Performance, New York University Working Paper.

Mayers, D. (1972) Non-marketable assets and capital market equilibrium under uncertainty, in Studies in the Theory of Capital Markets (edited by M.C. Jensen), Praeger Publishers, New York.

Mengden, A.E. and Hartzell, D. (1986) Real Estate Investment Trusts: Are They Stocks or Real Estate? Salomon Brothers Inc. 
Miles, M. and McCue, T. (1984) Commercial real estate returns, AREUEA Journal, 12(3), 35577.

Miles, M. and Rice, M. (1978) Toward a more complete investigation of the correlation of real estate investment yield to the rate evidenced in the money and capital markets: the individual investor's perspective, The Real Estate Appraiser and Analyst, 44(6), 8-19.

Musgrave, J.C. (1981) Fixed capital stock in the United States: revised estimates, Survey of Current Business, 61(2), 57-68.

Roll, R. (1977) Critique of the asset pricing theory's tests, Journal of Financial Economics, 4(2), 129-76.

Roulac, S.E. (1976) Can real estate returns outperform common stocks, Journal of Portfolio Management, 2(2), 26-43.

Sirmans, G. and Sirmans, C.F. (1987) The historical perspective of real estate returns, Journal of Portfolio Management, 13(3), 22-31.

Shapiro, S.S. and Wilk, M.B. (1965) An analysis of variance test for normality, Biometrika, $52(3), 591-611$.

Smith, K.V. and Shulman, D. (1976) The performance of equity real estate investment trusts, Financial Analysts Journal, 32(5), 61-6.

Stambaugh, R.F. (1982) On the exclusion of assets from tests of the two parameter model: a sensitivity analysis, Journal of Financial Economics, 10(3), 237-68.

US Department of Commerce (1986) Fixed Reproducible Tangible Wealth in the United States, 1925-85, US Government Printing Office, Washington, DC.

Zerbst, R.H. and Cambon, B.H. (1984) Real estate: historical returns and risk, Journal of Portfolio Management, 10(3), 5-20. 